\title{
РОЛЬ СІМЕЙНОГО ЛІКАРЯ В ПРОФІЛАКТИЦІ, РАННІЙ ДІАГНОСТИЦІ, ДИСПАНСЕРИЗАЦІ ТА РЕАБІЛІТАЦІ ХВОРИХ НА АЛКОГОЛІЗМ
}

\author{
○I. М. Карпінець
}

\author{
ДВНЗ «/вано-Франківський національний медичний університет»
}

РЕЗЮМЕ. 3 метою визначення можливостей і ролі лікаря загально практики-сімейно медицини у профілактиці, ранній діагностиці, диспансеризаці та реабілітаці хворих на алкоголізм проаналізовано світові і вітчизняні науковоінформаційні джерела та нормативно-правові акти (324 од.), а також результати медико-соціологічного дослідження 552 осіб, які знаходились на обліку у лікарів-наркологів закладів охорони здоров'я Івано-Франківсько області як залежні чи такі, що зловживають алкоголем, та 150 осіб групи порівняння. Обґрунтовано функціонально-структурну модель системи профілактики алкоголізму із комплексом удосконалених заходів, орієнтованих на $x$ виконання сімейними лікарями. Впровадження окремих елементів моделі у закладах охорони здоров'я Івано-Франківсько області засвідчило ефективність.

КЛЮЧОВІ СЛОВА: алкогольна залежність, профілактика, лікар загально практики- сімейно медицини.

Вступ. Алкоголь за сво ми медичними та соціальними наслідками - одна з найпріоритетніших проблем охорони здоров'я. Прямі та побічні економічні втрати внаслідок алкоголізаці населення завдають суттєво шкоди соціально-економічному розвитку кра ни через погіршення демографічно ситуаці, зростання травматизму, насильства в суспільстві і сім'ях, зниження продуктивності праці, збільшення безробіття та бідності $[1,2]$. Зокрема, в Укра ні алкоголізм є другим за вагомістю чинником ризику, який спричиняє 12 \% глобального тягара хвороб (18,3\% серед чоловіків і 4,3\% серед жінок), що підкреслює вагомість профілактики, раннього виявлення та ефективно диспансеризаці хворих [2].

Організація наркологічно допомоги в Укра ні, яка регламентується положеннями Закону «Про психіатричну допомогу» (2000), базується на пасивному виявленні і добровільному зверненні хворих за спеціалізованим лікуванням. Це, у поєднанні із психологічними особливостями перебігу захворювання (неусвідомлення довгий час своє хвороби і необхідності лікування) та тривалим приховуванням проблеми сім'ями хворих, часто призводить до запізнілого виявлення або й відсутності належно медично допомоги $[2,4]$.

Подолання багатогранно та поліетіологічно проблеми надмірного вживання алкоголю в суспільстві вимагає скоординованих дій державних органів, медичних працівників, громадських, релігійних та недержавних організацій а також хворих і членів $x$ сімей. Вагому роль у цьому, як зазначається у Європейському плані дій із скорочення шкідливого вживання алкоголю на 2012-2020 рр. (2011), може і повинен відігравати лікар загально практики - сімейно медицини (ЛЗП-СМ) [1, 3].

Мета дослідження. Визначити можливості і роль лікаря загально практики-сімейно медицини у профілактиці, ранній діагностиці, диспансеризаці та реабілітаці хворих на алкоголізм.
Матеріали і методи дослідження. Проаналізували світові і вітчизняні науково-інформаційні джерела та нормативно-правові акти (324 од.), а також результати медико-соціологічного ретроспективного дослідження 552 осіб, які перебували на обліку у лікарів-наркологів закладів охорони здоров'я Івано-Франківсько області як залежні чи такі, що зловживають алкоголем, та 150 осіб групи порівняння, які зверталися для профілактичного наркологічного огляду (для отримання наркологічного сертифікату) і за його результатами визнані такими, що не залежні і не зловживають алкоголем.

Результати й обговорення. На підставі міжнародних рекомендацій, діючо вітчизняно нормативно-правово бази та власних результатів дослідження [3, 5-7] обґрунтовано, розроблено та апробовано функціонально-структурну модель оптимізовано системи профілактики вживання алкоголю, що шкодить здоров'ю (рис. 1).

Стратегічно розроблена модель спрямована на поліпшення алкогольно ситуаці в суспільстві, забезпечення раннього виявлення осіб, які вживають алкоголь із шкодою для здоров'я, охоплення х своєчасним лікуванням, реабілітацію і ресоціалізацію хворих на алкогольну залежність.

Тактичні напрями досягнення заплановано стратегі включають комплекс удосконалених заходів первинно , вторинно та третинно профілактики алкогольно залежності з чітким розподілом функціональних взаємозв'язків між структурними елементами системи.

Як видно з рисунка 1, запропонована модель оптимізовано системи профілактики алкогольно залежності включає:

- існуючі елементи системи охорони здоров'я (наркологічна служба);

- функціонально удосконалені складові (конкретизація функцій, послідовності дій основних постачальників профілактичних послуг; підвищення інформованості населення); 

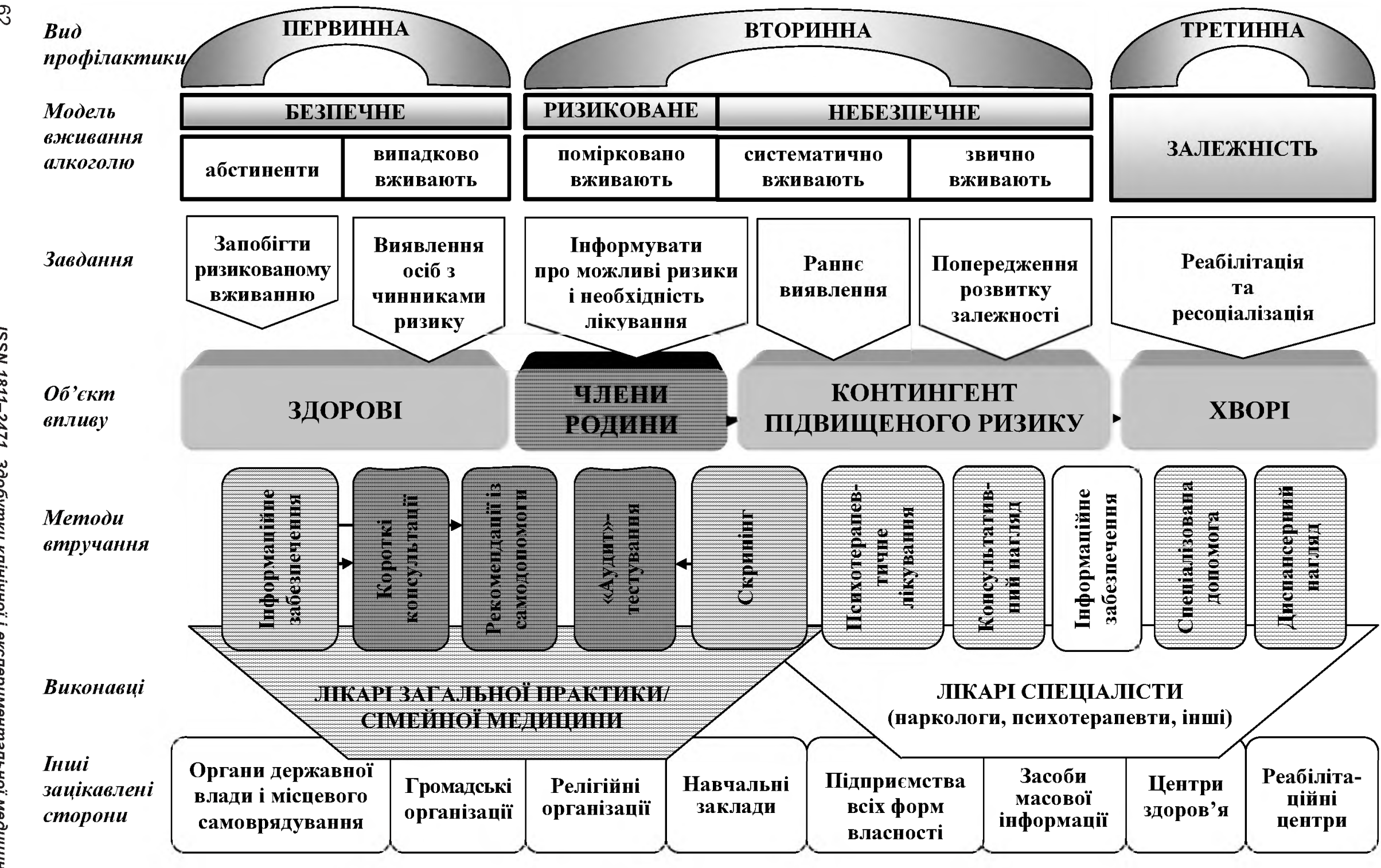

Примітка: $\square$ - існуючі елементи, $\square$ - частково змінені елементи, $\underline{\square .11|| \mid}$ - запропоновані елементи системи 
Оеляди літератури, ориаінальні дослідження, поеляд на проблему

- якісно нові елементи (алгоритм дій ЛЗП-СМ, спрямований на раннє виявлення осіб, які вживають алкоголь із шкодою для здоров'я; технологія інформування населення про ризики, пов'язані із алкоголем, і про можливість допомоги та лікування з метою скорочення шкідливого споживання - короткі консультаці, рекомендаці із самодопомоги; введення психологічного «аудит»-тестування на рівні первинно медично допомоги, розширення цільових об'єктів впливу профілактичних стратегій за рахунок близьких і рідних осіб, що вживають алкоголь із ризиком для здоров'я), взаємодія яких між собою надає системі нових якостей.

Як видно з рисунка 1, запропоновані нововведення передбачають диференціювання профілактичних та інших втручань залежно від моделі вживання алкоголю (відносно безпечно, ризиковано, небезпечно, адитивно ) [8] та адекватно до не групи спостереження: здорових, контингенту підвищеного ризику та хворих на алкоголізм.

В якості пріоритетних методів реалізаці завдань первинно і вторинно профілактики пропонується запровадити:

- адекватне інформаційне забезпечення населення;

- постійний моніторинг моделей споживання алкоголю і чинників ризику його вживання із шкідливими наслідками.

Ключовим виконавцем означених завдань визначено лікаря загально практики-сімейно медицини (ЛЗП-СМ) як професіонала, нормативними функціональними обов'язками якого є організація та забезпечення виконання базових профілактичних програм серед приписаного населення, а також консультування пацієнтів не тільки з медичних, але і з питань, які виходять за межі медицини, координація дій зацікавлених сторін. Знаючи кожну родину, соціально-економічний статус, соціальнопсихологічні взаємини, спосіб життя та медикобіологічний профіль, ЛЗП-СМ має можливість виділити осіб та сім' із чинниками ризику, у тому числі алкоголізму, проводити цільову просвітницьку роботу, виявляти осіб, що вживають алкоголь із шкодою для здоров'я та сформованою алкогольною залежністю, залучати і допомагати членам родини переконати таких пацієнтів звернутись за спеціалізованою допомогою тощо. Важливим $є$ також координація дій і співпраця ЛЗП-СМ з лікарями-спеціалістами (наркологом, психотерапевтом) у роботі з контингентом підвищеного ризику стосовно раннього виявлення та запобігання розвитку залежності.

Саме тому функці ЛЗП-СМ пропонується доповнити економічно раціональними та ефективними принципово новими технологіями, впровадження яких не вимагає значних додаткових затрат:
- короткими консультаціями, які повинні надавати інформацію про небезпеку алкоголю та пропонувати можливості отримання допомоги, мобілізувати громадську думку на підтримку ефективно алкогольно політики;

- скринінг-тестами для виявлення та моніторингу осіб із проблемними моделями вживання алкоголю, зокрема стандартизованим в Украні простим та надійним (92 \% чутливості і 93 \% специфічності), легким для користування тестом AUDIT (The Alcohol Use Disorders Identification Test) [4].

Щодо третинно профілактики (рис. 1), то запропоновані нововведення передбачають охоплення хворих на алкогольну залежність спеціалізованим лікуванням та диспансерним наглядом у лікаря-нарколога та контроль з боку ЛЗП-СМ за дотриманням пацієнтами рекомендацій і термінів контрольних наркологічних оглядів. Це дозволить значно знизити навантаження на вторинний і третинний рівні системи охорони здоров'я та сприятиме підвищенню ефективності лікування та диспансеризаці. Крім того, на ЛЗП-СМ, поряд з лікарями-спеціалістами та іншими зацікавленими сторонами (органами місцевого самоврядування, недержавними громадськими організаціями, засобами масово інформаці, реабілітаційними центрами тощо) припадає значний обсяг реалізаці заходів із реабілітаці та ресоціалізаці хворих на алкогольну залежність.

3 метою реалізаці основних елементів розроблено моделі (рис. 1) співробітниками обласного наркологічного диспансеру з 2010 року налагоджені відповідні тренінги на кафедрі терапі і сімейно медицини факультету післядипломно освіти ДВНЗ «Івано-Франківський національний медичний університет» на циклах передатестаційних та тематичного удосконалення лікарів загально практики - сімейно медицини.

Впровадження пропозицій у закладах охорони здоров'я Івано-Франківсько області довело $\mathrm{x}$ ефективність щодо поліпшення раннього виявлення (зросла частота звернень до лікарівнаркологів на 5,6 \% і повнота охоплення консультативним наглядом осіб, що зловживають алкоголем, але ще не мають залежності, на 15,4\%), та охоплення хворих диспансерним наглядом (на 6,6 \%) і спеціалізованим лікуванням (на 7,1\%).

Висновки. 1. Запропоновано функціональноструктурну модель системи профілактики алкоглізму із комплексом удосконалених заходів, орієнтованих на $\mathrm{x}$ виконання сімейними лікарями.

2. Впровадження окремих елементів моделі оптимізовано системи профілактики алкоголізму у закладах охорони здоров'я Івано-Франківсько області засвідчило медико-соціальну та економічну ефективність. 
Оеляди літератури, оригінальні дослідження, поеляд на проблему

Перспективи подальших досліджень полягають у подальшому впровадженні оптимізо-

вано системи профілактики алкоголізму в практику закладів охорони здоров'я.

\section{ЛІТЕРАТУРА}

1. Глобальная стратегия сокращения вредного упо требления алкоголя / Всемирная организация здравоохранения. - Женева, 2010. - 42 с.

2.Грузєва Т. С. Скорочення вживання алкоголю пріоритетний напрямок охорони здоров'я / Т. С. Грузєва, Л.І. Галієнко, Г.В.Іншакова // Всесвітній день здоров'я 2012 р. : тези міжнар. наук.- практ. конф. // Східноєвропейський журнал громадського здоров'я. - 2012. - № 1 (17). - С. 134-136.

3. Европейский план действий по сокращению вредного употребления алкоголя, 2012-2020 гг. [Электронный ресурс] / Всемирная организация здравоохранения. Европейское региональное бюро. - Копенгаген, 2011. - 32 с. - Режим доступа: http://www.euro.who. int/_data/assets/pdf_file/0007/147733/wd13R_AlcoholPlan.pdf
4. Зріз алкогольно ситуаці в Укра ні 2012 (дані 2011 року) / Вієвський А. М., Жданова М. П., Сидяк С. В. [та ін.]. - К. : ДУУММЦАН МОЗ Укра ни, 2012. - 25 с.

5. Карпінець І. М. Особливості соціально-економічного статусу хворих на алкоголізм / І. М. Карпінець // Архів клінічно медицини. - 2011. - № 2 (17). - С. 21- 24.

6. Карпінець І. М. Особливості соціально-психологічно адаптаці хворих на алкоголізм / І. М. Карпінець // Галицький лікарський вісник. - 2011. - Т. 18, № 4. - С. 34- 38.

7. Карпінець І. М. Особливості індивідуального способу життя хворих на алкоголізм / І. М. Карпінець // Вісник соціально гігієни та організаці охорони здоров'я Укра ни. 2011. - № 4. - С. 27- 32.

8. Шабанов П. Д. Наркология / П. Д. Шабанов. Практическое руководство для врачей. - М. : ГЕОТАРМЕД, 2003. - $560 \mathrm{c}$.

\title{
ROLE OF FAMILY PHYSICIAN IN THE PREVENTION, EARLY DIAGNOSIS, CLINICAL EXAMINATION AND REHABILITATION OF PATIENTS WITH ALCOHOLISM
}

\author{
OI. M. Karpinets
}

\section{SHEI «Ivano-Frankivsk National Medical University»}

SUMMARY. To determine the capabilities and role of general practitioners in the prevention, early diagnosis, clinical examination and rehabilitation of patients with alcoholism domestic and global scientific information sources and regulatory legal acts (324 units) was analyzed. The results of medical and sociological research of 552 persons registered at narcologists in health care institutions of lvano-Frankivsk region as alcohol abusers and 150 persons from comparison group have also been investigated. Functional-structural model of the system for the prevention of alcoholism with complex advanced measures aimed at the implementation by family physicians has been substantiated. Implementation of certain elements of the model in healthcare institutions of Ivano-Frankivsk region has proved its effectiveness.

KEY WORDS: alcohol addiction, prevention, general practitioners. 